\title{
Germination analysis in different substrates of Tabebuia cassinoides (Lam.) DC. of high restinga forest, Ubatuba, São Paulo, Brazil
}

\section{Aline Paulichen ${ }^{1}$ and Leandro Tavares Azevedo Vieira ${ }^{2}$}

\author{
${ }^{1}$ Mackenzie Presbyterian University. Biology Graduate Course. Rua Piauí, 181. São \\ Paulo, Brazil (CEP 01241-001). \\ ${ }^{2}$ Mackenzie Presbyterian University. Herbarium MACK. Rua Piauí, 181, 1st floor. \\ São Paulo, Brazil (CEP 01241-001). Email: leandrotavieira@gmail.com.
}

\begin{abstract}
Tabebuia cassinoides (Lam.) DC., popularly known as caixeta, is a well-known species for its timber harvesting. The species is dominant in flooded high restinga forest where we collected fruits and seeds from Núcleo Picinguaba, Serra do Mar State Park, Ubatuba, Brazil. The restinga, or sandy coastal forest, is a type of vegetation formed by sandy sediments from marine deposition. Thus, we asked whether the sand substrate would produce better germination indices than germitest paper or vermiculite due to its similarity to specie natural condition. We placed a total of 60 seeds in Gerboxes with duplicates of the three substrates. We placed each Gerbox with ten seeds randomly in the germination chamber at $30^{\circ} \mathrm{C}$, photoperiod of $12 \mathrm{~h}$, and water at proper field capacity. We periodically evaluated the seeds and analyzed the germination percentage (\%), germination speed index (GSI), and mean germination time (MGT). Our results showed that sand was the most favorable substrate for germination of caixeta seeds for at least 35 days, corroborating the initial hypothesis. We hope that our results can improve the sustainable management and conservation of the species.
\end{abstract}

Keywords: Atlantic Forest: Caixeta; Germination chamber; Seeds.
Received

May 27, 2020

Accepted

August 22, 2020

Released

August 31, 2020

Full Text Article

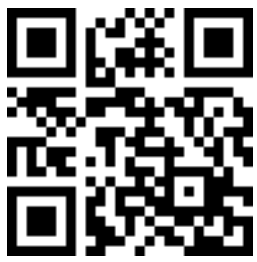

ORCiD

(D) $0000-0001-5713-768 \mathrm{X}$ Aline Paulichen

D 0000-0003-4333-4417

Leandro Tavares

Azevedo Vieira

\section{Introduction}

The Atlantic Forest is the second-largest forest of the American continent, which extends along the Brazilian coast (Tabarelli et al., 2005; Ribeiro et al., 2009). Historically, the Atlantic Forest stretched continuously covering 15\% of Brazilian territory and spread over seventeen states, but nowadays, the fragmentation of the forests is observed as a consequence of deforestation and anthropic actions, remaining only $11 \%$ to $16 \%$ of 
original coverage (Ribeiro et al., 2009). Due to high rates of richness and endemism, associated with a high threat by deforestation and fragmentation of this domain, the Atlantic Forest is considered one of the 35 biodiversity hotspots for conservation known worldwide (Mittermeier et al., 2011).

The main occurrence of the Atlantic Forest occurs on Brazilian coastal and by its physiographic and biogeographic conditions forms a relatively homogeneous and extensive complex, being called the Atlantic Forest sensu strictu (s.s.) (Ab'Sáber, 2003). However, considering all physiognomies, the Atlantic Forest sensu lato (s.l.) is a phytogeographic domain that occurs in a spatial set that has millions of square kilometers of area, besides different types of soils, relief features, forms of vegetation and differentiated climatic-hydrological conditions (Fiaschi and Pirani, 2009).

The Atlantic Forest presents a variety of forest ecosystems with several characteristics related to climatic and geographical differences across its extension. One of the most important factors is the distance from the ocean, which has a direct influence on rainfall distribution and duration of seasonality, hence, a direct influence on the distribution and diversity of these ecosystems(Morellato and Haddad, 2000; Eisenlohr and Oliveira-Filho, 2015). Thus, including variation according to latitude, longitude, relief, and climate, the Atlantic Forest presents mainly the following forest formations: ombrophilous dense forest; ombrophilous mixed forest; semideciduous seasonal forest; deciduous seasonal forest; high-altitude grasslands; swamps; mangroves and restingas (Scarano, 2002; Ribeiro et al., 2011).

The restinga, or sandy coastal forest, is a type of vegetation that covers the coastal plains formed by sandy sediments from marine deposition through retreat of the sea level from different geological periods (Cerqueira, 2000; Gomes et al., 2007). This "pioneer" vegetation under the marine influence is a gradient from herbaceous to woody plants (Marques et al., 2011). Distance from the sea, local topography, and structure of vegetation itself influence the restinga physiognomies (Martini et al., 2014).

The high restinga forest is a closed canopy tree physiognomy with predominant arboreal stratum, and the height varies between 10 and $15 \mathrm{~m}$ (Brasil, 2009; Martini et al., 2014). Where the water table is shallow and the soils remain flooded most of the year, the species Tabebuia cassinoides (Lam.) DC. is dominant (Peixoto, 1992). The caixeta, a vernacular name of $T$. cassinoides, has been intensively harvested in the last 70 years due to its timber quality and versatility, which is used for the manufacture of pencil, clogs, musical instruments, toys, and crafts (Castro, 2002; Martinelli and Moraes, 2013). The exploitation occurs from natural populations (Cavallari Neto, 2004) with few viable subpopulations for commercial exploitation, and it is considered endangered in the Red List of Brazilian Flora of threatened species (Cavallari Neto, 2004; Martinelli and Moraes, 2013).

The harvest of caixeta and other species from high restinga forest causes negative impacts such as loss of soil fertility, change in water resources, reduction of forest cover and biodiversity, and loss of genetic diversity among species (Waldhoff et al., 2001; Castro, 2002; Cavallari Neto, 2004). For economic exploitation in managed areas, the caixeta must have a minimum of $15 \mathrm{~cm}$ diameter at breast high for cut and requires maintenance at least 20 healthy, mature, and in reproductive stage individuals per hectare (São Paulo, 1992). However, it is recommended at least 75 reproductive trees per hectare, evenly distributed throughout the area, and a 16-year cutting cycle (Martinelli and Moraes, 2013).

Germination studies are needed to attain an adequate management plan that allows the exploitation of $T$. cassinoides, including seed interaction with the environment in which it lives, the influence of abiotic factors such as soil, climate, precipitation, and photoperiod, and biotic factors such as the presence of toxic substances, phytohormones, and parasites (Ferreira and Borghetti, 2004). There are few recommendations for analysis 
of tropical rainforest species since these species vary greatly concerning dormancy types and time required for germination onset (Cardoso, 2004).

Since the Tabebuia cassinoides occurs in a flooded high restinga forest, we asked which is the best substrate for germination of its seeds. Many tropical trees have higher germination indices in paper or vermiculite substrates (Mello and Barbedo, 2007; Martins et al., 2012), however, we hypothesize that sand substrate would be better due to its similarity to the restingas natural condition.

\section{Materials and methods}

\section{Species of study}

The Tabebuia cassinoides (Lam.) DC., Family Bignoniaceae, popularly known as Caixeta or Pau-Caixeta, is a Brazilian endemic species that occur in the ombrophilous dense forest of Atlantic Forest at São Paulo, Rio de Janeiro, Minas Gerais e Espírito Santo States (Lohmann, 2019). T. cassinoides is a hygrophilic plant that occurs in soils permanently humid or flooded in Brazilian coastal range (Lorenzi, 2008), presenting formation of adventitious roots and hypertrophic lenticels which are important characteristics to tolerance flooding (Kuniyoshi, 1993).

T. cassinoides has 6-12 m height, trunk $30-40 \mathrm{~cm}$ in diameter, simple leaves $12-22$ $\mathrm{cm}$ long without stipple, flowering season between July and January and occurrence of its ripe fruit between October and March (Lorenzi, 2008). The fruits are capsule-shaped, linear-oblong, where the seeds are dispersed by the wind since it is a winged seed (Carvalho, 2003; Kolb and Joly, 2010).

\section{Study area and fruit collection}

We collected seeded fruits in a flooded high restinga forest fragment, located in Núcleo Picinguaba, Serra do Mar State Park, Ubatuba Municipality, São Paulo State, Brazil $\left(23^{\circ} 21^{\prime} 10.57^{\prime \prime} \mathrm{S}\right.$ and $44^{\circ} 51^{\prime} 5.699^{\prime \prime} \mathrm{W}, 10 \mathrm{~m}$ elevation). The region yearly average temperature of the region is $22.6^{\circ} \mathrm{C}$, and ranging between a minimum average of $17.8^{\circ} \mathrm{C}$ and a maximum average of $27.3^{\circ} \mathrm{C}$ (CEPAGRI, 2017). The yearly average rainfall is 2.154 $\mathrm{mm}$, with a rainy season from November to April (Rolim et al., 2007).

In the study area, we identified five individuals of $T$. cassinoides with the largest diameters at breast height (DBH) and collected their fruits with seeds. We collected on December 5, 2018, with the aid of high pruning shears to reach the highest branches. We incorporated two vouchers in Herbarium Amélia Vera Guimarães de Sousa (MACK) of Mackenzie Presbyterian University under numbers 3199 and 3200. Following Ramos (1980), we visually qualified the seeds searching for pathogens presence or predation signs, then underwent kiln drying at $42{ }^{\circ} \mathrm{C}$ for $3 \mathrm{~h}$ and stored in multiwall paper bags at room temperature and humidity controlled with the aid of a hygrometer during 60 days.

\section{Seed germination}

We carried out the seed germination tests in germitest paper, vermiculite, and sand substrates placed in Gerboxes, which are a germination box made of transparent plastic $(11 \times 11 \mathrm{~cm})$. We sterilized all Gerboxes with $70 \%$ alcohol. We kept the sand and germitest paper substrates for $12 \mathrm{~h}$ in kiln drying at $100{ }^{\circ} \mathrm{C}$ to minimize any contamination, while we opened the vermiculite substrate package before the experimentation.

We weighed each substrate with a semi-analytical electronic balance (Gehaba, model BK 3000, São Paulo, Brazil) to properly attain the field capacity, which varies according to each substrate type (Brasil, 2009). Is indicated a water volume an amount equivalent to 2.0-3.0 times of the weight of germitest paper, hereafter named only paper, to attain the field capacity, while $60 \%$ of the weight of sand and vermiculite (Brasil, 2009). 
Therefore, according to field capacity calculation, we initially moistened the seeds with 1 $\mathrm{mL}$ of water in vermiculite, paper $3 \mathrm{~mL}$, and sand $4.5 \mathrm{~mL}$.

We placed ten seeds in each Gerbox of the three types of substrates performed in duplicates; thus, a total of 60 seeds in six Gerboxes. We placed the Gerboxes randomly in the germination chamber (Tecnal model TE-4013, Piracicaba, Brazil). The size of the seeds is often the factor that might render unviable a higher number of tested seeds due to lack of space in small gerboxes or the germination chamber (Ferraz and Calvi, 2010), which were our scenario. We irrigated every two days, respecting the field capacity of each substrate. We set the germination chamber at $30^{\circ} \mathrm{C}$ and a photoperiod of $12 \mathrm{~h}$, as indicated by Bianchetti et al. (1995). We periodically counted the number of germinated seeds for 35 days, and we considered the germinated seeds those with approximately $2 \mathrm{~mm}$ of radicle emergence (Brasil, 2009).

\section{Data analysis}

To test whether the total number of germinated seeds differed between substrates, we performed at the $5 \%$ significance level the goodness-of-fit Chi-square test $\left(x^{2}\right)$ on Past 3 software (Hammer et al., 2001). We analyzed the seed germination percentage according to $15,25,35$ days elapsed after planting, which we identified as the days that the treatments had more distinction in the number of germinated seeds.

For each substrate, we calculated germination percentages, the germination speed indexes (GSI), and mean germination time (MGT). We calculated the GSI by the sum of seeds number germinated in each day evaluated and divided by the number of days elapsed between sowing and germination (Maguire, 1962). We considered as partial GSI the number of germinated seeds divided by the number of respective intervals of 15,25 and 35 days. We calculated the MGT by the sum of germinated seeds number per day multiplied by respective incubation time divided by the sum of germinated seeds number (Ranal and Santana, 2006).

\section{Results}

At the end of 35 days of the experiment, out of 60 seeds of Tabebuia cassinoides placed in the germination chamber, 24 seeds germinated (40\%). Sand substrate obtained the highest percentage of germinated seeds $(80 \%)$ significantly when compared to paper $(25 \%)$ and vermiculite (15\%; Table 1$)\left(X^{2}=12.25 ; \mathrm{p}=0.002\right)$.

Table 1. Absolute and percentage of germinated seeds of Tabebuia cassinoides considering 20 seeds sowing in each substrate.

\begin{tabular}{|l|c|c|}
\hline Treatment & Total germinated & Percentage (\%) \\
\hline Vermiculite & 3 & 15 \\
\hline Paper & 5 & 25 \\
\hline Sand & 16 & 80 \\
\hline
\end{tabular}

Evaluating through time, in the first 15 days of germination test, only one seed in sand substrate germinated, but after 25 days, $T$. cassinoides seeds germination reached levels of $50 \%, 20 \%$ and $5 \%$ on the sand, paper, and vermiculite substrates, respectively (Figure 1). At the end of the test, at 35 days, the germination proportion was maintained. 


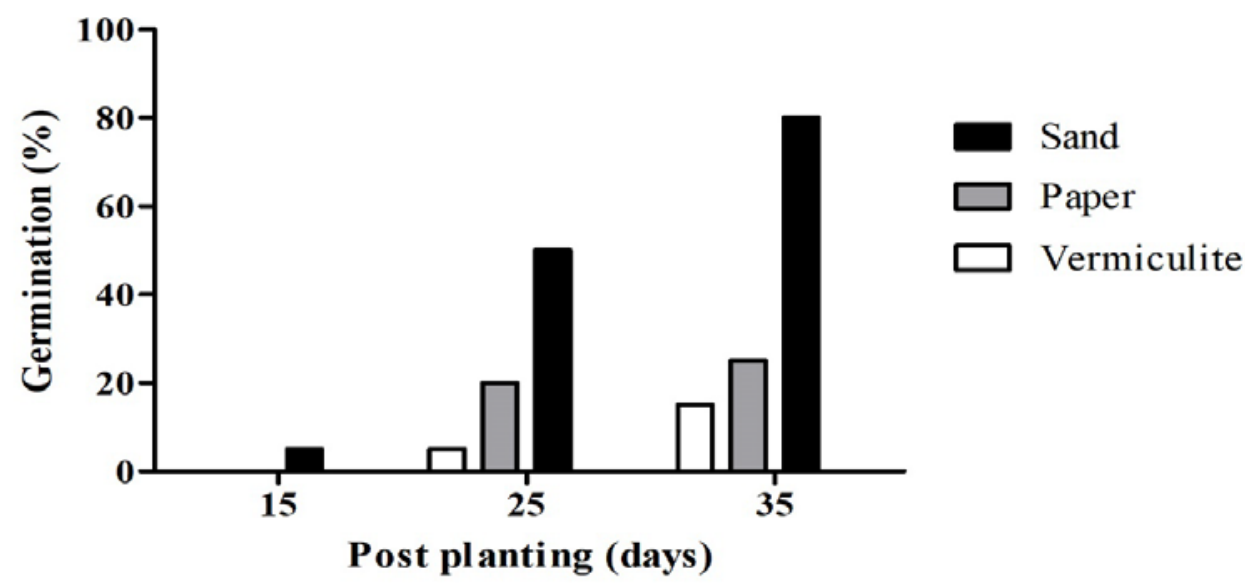

Figure 1. Germination percentages of Tabebuia cassinoides seeds according to different types of substrates and intervals of post-planting in days.

The type of substrate also showed differences in seed germination speed. According to GSI, sand substrate had the highest germination velocity $(0.60)$, followed by paper (0.19) and vermiculite (0.10). Analyzing the partial calculations of GSI, a peak of germination velocity was on day 25 in paper and sand substrates (Figure 2).

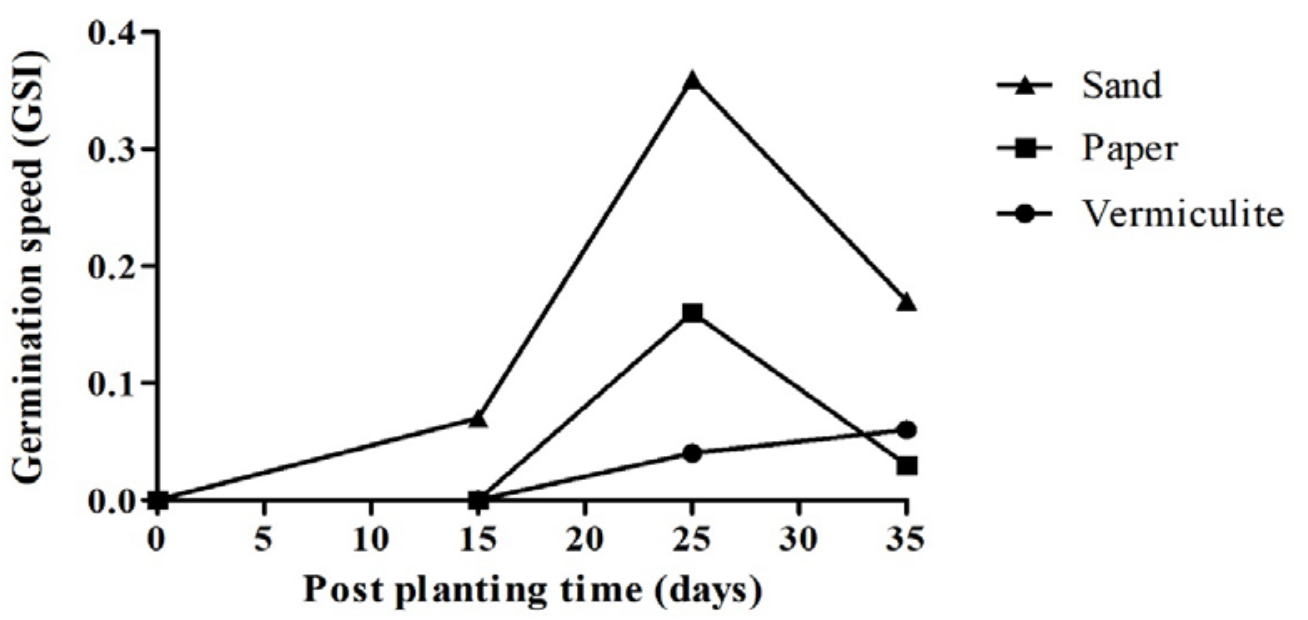

Figure 2. Partial germination speed indexes of Tabebuia cassinoides seeds according to different types of substrates and intervals of post-planting in days.

The mean germination times were similar between treatments, and paper substrate presented the shortest mean time of germination (27 days), followed by sand (28 days) and vermiculite (32 days). The germination test for up to 35 days allowed the observation of a higher percentage of germination but, consequently, increased the MGT. 


\section{Discussion}

The highest percentage and germination speed index was obtained on the sand substrate, showing $80 \%$ germination at the end of the experiment and the highest GSI. Also, in the first 15 days after sowing, it was observed that only seeds on sand substrate germinated, while seeds on paper and vermiculite substrates not started. The results indicated sand as the best substrate to Tabebuia cassinoides germination since all duplicates of each substrate placed in the germination chamber were submitted to the same temperature at $30^{\circ} \mathrm{C}$, same photoperiod of $12 \mathrm{~h}$, and the proper field capacity of each substrate.

Our results were similar to those obtained by Bianchetti et al. (1995), which indicated the optimal germination condition of Tabebuia cassinoides seeds was in the sand substrate at $30{ }^{\circ} \mathrm{C}$. This temperature was an optimal germination condition for other Bignoniaceae seeds, found for Handroanthus impetiginosus (Mart. ex DC.) Mattos and Handroanthus serratifolius (Vahl) S. Grose (Oliveira et al., 2005). For other related species, the results indicated similar temperatures to attain an optimum germination rate, such as Handroanthus serratifolius, between temperature ranges of $20^{\circ} \mathrm{C}$ and $30{ }^{\circ} \mathrm{C}$ and Tabebuia roseoalba (Ridl.) Sandwith, at an ideal temperature of $30^{\circ} \mathrm{C}$ (Santos et al., 2005; Stockman et al., 2007). Maciel et al. (2013), analyzing the seedling length of species Jacaranda mimosifolia D. Don obtained better results when the seeds were at temperatures of $25{ }^{\circ} \mathrm{C}$ to $30^{\circ} \mathrm{C}$.

Regarding substrates types, Bovolini et al. (2015) found for Jacaranda micrantha (Cham.) that sand substrate combined with the temperature $25{ }^{\circ} \mathrm{C}-30{ }^{\circ} \mathrm{C}$ was adequate to provide higher values of germination speed index and for seedling development. According to Borba-Filho (2006), Handroanthus serratifolius seeds on the sand substrate, between five and ten days, the specie obtained the highest values of germination percentage (94\%) and germination speed. For Tabebuia cassinoides, Fowler et al. (1999) describe that the highest germination percentage was in sandy soils $(77.3 \%)$, values very similar to our results.

Considering the germination speed index (GSI), Santos et al. (1994), studying Mimosa caesalpiniifolia Benth. (Fabaceae), and Bocchese et al. (2008), studying Handroanthus heptaphylla (Vell.) Mattos, obtained that sandy substrate has higher GSI due to greater ease of emergency of seedlings and lower difficulty to break the physical barrier of soil through its root system. This conclusion corroborates our results for Tabebuia cassinoides in the sand substrate, while the other substrates used in our study do not impose a high physical barrier for the seedling.

The peak of germination at 25 days, indicated by partial GSI, and about 27-28 days by MGT, evidenced that both paper and sand substrates presented similar germination behaviors, however, the germination even lasted until 35th day with good results. Bianchetti et al. (1995) performed germination analyses until the 28th day, indicates that germination of T. cassinoides prolonged for at least four weeks for final evaluation. Thus, we highlighted that the germination must be performed until four to five weeks to obtain a reasonable total amount of germinated seeds.

According to Martins et al. (2012), the species Handroanthus chrysotrichus (Mart. ex DC.) Mattos, which occurs in the Atlantic Rainforest and gallery forest of the Cerrado domain, presented a higher germination percentage on the vermiculite substrate, which has similar characteristics of clay soil where this species occurs. Temperature and soil have a grand influence on species germination, and these factors should limit the distribution of plant species along the restinga vegetation (Sabonaro, 2011). Since T. cassinoides occur dominantly in high restinga forest with high water infiltration due to the high proportion of sand and low clay content, the germination experiment showed better results on the sand substrate, corroborating our hypothesis. 
The importance of knowledge about the germination of species is crucial to establish the best germination success rate regarding the influence of abiotic factors as soil and temperature. By improving the understanding of Tabebuia cassinoides germination, it is possible to develop better sustainable forest management aiming conservation and reintroducing new individuals in nature, since this species has high levels of exploitation due to its high economic value.

\section{Conclusion}

Our results indicated that different substrates types had a direct influence on the germination of caixeta. The best germination condition for Tabebuia cassinoides seeds is on the sand substrate, at $30{ }^{\circ} \mathrm{C}$, for at least 35 days in the germination chamber, with a photoperiod of $12 \mathrm{~h}$, and water irrigation reaching $60 \%$ of substrate weight. These conditions are similar to those of their natural environments.

\section{Acknowledgments}

We thank Guilherme G. de Almeida and Kayhe P. A. C. Franco for the commendable support in fieldwork. We thank Núcleo Picinguaba, Serra do Mar State Park, for all support during the Field Taxonomy Course (\#009.408/2018) when fruits were collected. We submitted to the national genetic heritage management system and associated traditional knowledge and was registered in SisGen, in compliance with the provisions of Law 13,123/2015 and certificate number A8298F1.

\section{Conflicts of interest}

The authors declare that they have no conflicts of interest.

\section{References}

Ab'Sáber, A. N. Os domínios de natureza no Brasil: potencialidades paisagísticas. São Paulo: Ateliê Editorial, 2003.

Bianchetti, A.; Ramos, A.; Martins, E. G.; Fowler, J. A.; Alves, V. F. Substratos e temperaturas para a germinação de sementes de caixeta (Tabebuia cassinoide). Colombo: Embrapa Florestas, 1995. (Comunicado técnico).

Bocchese, R. A.; Oliveira, A. K. M.; Melotto, A. M.; Fernandes, V.; Laura, V. A. Efeito de diferentes tipos de solos na germinação de sementes de Tabebuia heptaphylla, em casa telada. Cerne, v. 14, no. 1, p, 62-67, 2008.

Borba-Filho, A. B. Aspecto da germinação e da conservação de sementes de espécie do gênero Tabebuia (Bignoniaceae). São Carlos: Universidade Federal de São Carlos, 2006.

Bovolini, M. P.; Maciel, C. G.; Brum, D. L.; Muniz, M. F. B. Influência de temperatura e substrato na germinação e no vigor de sementes de Jacaranda micrantha Cham. Revista de Ciências Agroveterinárias, v. 14, no. 3, p. 203-209, 2015. https://doi.org/10.5965/ 223811711432015203

Brasil. Regras para análise de sementes. Brasília: Ministério da Agricultura, Pecuária e Abastecimento, 2009. 
Brasil. Resolução CONAMA no 417, de 23 de novembro de 2009. Dispõe sobre parâmetros básicos paradefinição de vegetação primária e dos estágios sucessionais secundários da vegetação de Restinga na Mata Atlântica e dá outras providências. Available from: <http://www2.mma.gov.br/port/conama/legiabre.cfm?codlegi=617>. Accessed on: Feb. 23, 2020.

Cardoso, V. J. Dormência: estabelecimento do processo. In: Ferreira, A. G.; Borghetti, F. (Eds.). Germinação: do básico ao aplicado. Porto Alegre: Artmed, 2004. p. 95-108.

Carvalho, P. E. R. Espécies arbóreas brasileiras. Brasília: Embrapa Informações Tecnológica, 2003.

Castro, R. C. F. Análise econômica do manejo da caixeta Tabebuia cassinoides (Lam.) DC na Região do Vale do Ribeira-SP: um estudo de caso. São Paulo: Universidade de São Paulo, 2002.

Cavallari Neto, M. Efeito do manejo na diversidade genética de populações naturais de Tabebuia cassinoides Lam (DC), por marcadores isoenzimáticos. São Paulo: Universidade de São Paulo, 2004. https://doi.org/10.11606/D.11.2004.tde-24112004101125

CEPAGRI - Centro de Pesquisas Meteorológicas e Climáticas Aplicadas à Agricultura. Clima dos municípios paulistas: Ubatuba. São Paulo: CEPAGRI, 2017.

Cerqueira, R. Biogeografia das restingas. Ecologia de Restingas e Lagoas Costeiras, v. 1, p. 65-75, 2000.

Eisenlohr, P. V.; Oliveira-Filho, A. T. Revisiting patterns of tree species composition and their driving forces in the atlantic forests of Southeastern Brazil. Biotropica, v. 47, no. 6, p. 689-701, 2015. https://doi.org/10.1111/btp.12254

Ferraz, I.; Calvi, G. Teste de germinação. In: Lima Jr, M. J. (Ed.). Manual de procedimentos de análise de sementes florestais. Manaus: UFAM, 2010.

Ferreira, A. G.; Borghetti, F. Germinação: do básico ao aplicado. Porto Alegre: Artmed, 2004.

Fiaschi, P.; Pirani, J. R. Review of plant biogeographic studies in Brazil. Journal of Systematics and Evolution, v. 47, no. 5, p. 477-496, 2009. https://doi.org/10.1111/ j.1759-6831.2009.00046.x

Fowler, J. A. P.; Curcio, G. R.; Rachwal, M. F. G ; Kuniyoshi, Y. Germinação e vigor de sementes de Tabebuia cassinoides (Lam.) DC coletadas em diferentes caxetais do litoral paranaense. Colombo: EMBRAPA-CNPF, 1999.

Gomes, F. H.; Vidal-Torrado, P.; Macías, F.; Gherardi, B.; Perez, X. L. O. Solos sob vegetação de restinga na Ilha do Cardoso (SP): I - caracterização e classificação. Revista Brasileira de Ciência do Solo, v. 31, p. 1563-1580, 2007. https://doi.org/10.1590/S010006832007000600033

Hammer, Ø.; Harper, D. A.; Ryan, P. D. PAST: Paleontological statistics software package for education and data analysis. Palaeontologia Electronica, v. 4, no. 1, p. 1-9, 2001. Available from: <https://palaeo-electronica.org/2001_1/past/past.pdf $>$. Accessed on: Feb. 23, 2020.

Kolb, R. M.; Joly, C. A. Germination and anaerobic metabolism of seeds of Tabebuia cassinoides (Lam.) DC subjected to flooding and anoxia. Flora-Morphology, Distribution, Functional Ecology of Plants, v. 205, no. 2, p. 112-117, 2010. https://doi.org/10.1016/j.flora.2009.01.001 
Kuniyoshi, Y. S. Aspectos morfo-anatômicos do caule, raiz e folha de Tabebuia cassinoides (Lam.) DC (Bignoniaceae) em diferentes fases sucessionais no litoral do Paraná. Curitiba: Universidade Federal do Paraná, 1993.

Lohmann, L. G. Tabebuia in Flora do Brasil 2020 em construção. Rio de Janeiro: Jardim Botânico do Rio de Janeiro, 2019.

Lorenzi, H. Árvores brasileiras: manual de identificação de plantas arbóreas nativas do Brasil. São Paulo: Plantarum, 2008.

Maciel, C. G.; Bovolini, M. P.; Finger, G.; Pollet, C. S.; Muniz, M. F. B. Avaliação de temperaturas e substratos na germinação de sementes de Jacaranda mimosifolia D. Don. Floresta e Ambiente, v. 20, p. 55-61, 2013. https://doi.org/10.4322/floram.2012.070

Maguire, J. D. Speed of germination: Aid in selection and evaluation for seedling emergence and vigor. Crop Science, v. 2, no. 2, p.176-177, 1962. https://doi.org/10.2135/ cropsci1962.0011183X000200020033x

Marques, M. C. M.; Swaine, M. D.; Liebsch, D. Diversity distribution and floristic differentiation of the coastal lowland vegetation: Implications for the conservation of the brazilian atlantic forest. Biodiversity and Conservation, v. 20, no. 1, p. 153-168, 2011. https://doi.org/10.1007/s10531-010-9952-4

Martinelli, G.; Moraes, M. A. Livro vermelho da flora do Brasil. 1. ed. Rio de Janeiro: Instituto de Pesquisas Jardim Botânico do Rio de Janeiro, 2013.

Martini, A. M. Z.; Castanho, C. T.; Pannuti, M. I. R.; Stuart, J.; Jesus, F. M.; Oliveira, A. A. Restinga e ecologia. In: Azevedo, N. H.; Martin, A. M. Z.; Oliveira, A. A.; Scarpa, D. L. (Orgs.). Ecologia na restinga: uma sequência didática argumentativa. São Paulo: Petrobrás, USP IB, LabTrop/BioIn, 2014.

Martins, C. C.; Machado, C. G.; Santana, D. G.; Zucareli, C. Vermiculita como substrato para o teste de germinação de sementes de ipê-amarelo. Semina: Ciências Agrárias, v. 33, no. 2, p. 533-540, 2012. https://doi.org/10.5433/1679-0359.2012v33n2p533

Mello, J. I. O.; Barbedo, C. J. Temperatura, luz e substrato para germinação de sementes de pau-brasil (Caesalpinia echinata Lam., Leguminosae - Caesalpinioideae). Revista Árvore, v. 31, p. 645-655, 2007. https://doi.org/10.1590/S0100-67622007000400009

Mittermeier, R. A.; Turner, W. R.; Larsen, F. W.; Brooks, T. M.; Gascon, C. Global biodiversity conservation: The critical role of hotspots. In: Zachos, F. E.; Habel, J. C. (Eds.). Biodiversity hotspots: Distribution and protection of conservation priority areas. Heidelberg: Springer, 2011.

Morellato, L. P. C.; Haddad, C. F. B. Introduction: The Brazilian atlantic forest. Biotropica, v. 32, no. 4b, p. 786-792, 2000. https://doi.org/10.1111/j.1744-7429.2000.tb00618.x

Oliveira, L. M.; Carvalho, M. L. M.; Silva, T. T. A.; Borges, D. I. Temperatura e regime de luz na germinação de sementes de Tabebuia impetiginosa (Martius ex A. P. de Candolle) Standley e T. serratifolia Vahl Nich. - Bignoniaceae. Ciência e Agrotecnologia, v. 29, p. 642-648, 2005. https://doi.org/10.1590/S1413-70542005000300020

Peixoto, A. L. Vegetação da costa atlântica: Floresta Atlântica. Rio de Janeiro: Alumbramento, 1992.

Ramos, A. Influência de cinco tipos de embalagens na germinação e no vigor de sementes de angico-Parapiptadenia rigida (Benth) Brenan, caixeta-Tabebuia cassinoides (Lam) DC. e caroba-Jacaranda micrantha Cham. armazenadas em câmara fria e à temperatura ambiente. Curitiba: Universidade Federal do Paraná, 1980.

Braz. J. Biol. Sci., 2020, Vol. 7, No. 16, p. 165-174. 
Ranal, M. A.; Santana, D. G. How and why to measure the germination process? Brazilian Journal of Botany, $\quad$ v. 29, p.1-11, 2006. https://doi.org/10.1590/S010084042006000100002

Ribeiro, M. C.; Martensen, A. C.; Metzger, J. P.; Tabarelli, M.; Scarano, F.; Fortin, M. J. The Brazilian atlantic forest: A shrinking biodiversity hotspot. In: Zachos, F. E.; Habel, J. C. (Eds.). Biodiversity hotspots: Distribution and protection of conservation priority areas. Heidelberg: Springer, 2011.

Ribeiro, M. C.; Metzger, J. P.; Martensen, A. C.; Ponzoni, F. J.; Hirota, M. M. The Brazilian Atlantic Forest: How much is left, and how is the remaining forest distributed? Implications for conservation. Biological Conservation, v. 142, no. 6, p. 1141-1153, 2009. https://doi.org/10.1016/j.biocon.2009.02.021

Rolim, G. S.; Camargo, M. B. P.; Lania, D. G.; Moraes, J. F. L. Classificação climática de Köppen e de Thornthwaite e sua aplicabilidade na determinação de zonas agroclimáticas para o Estado de São Paulo. Bragantia, v. 66, no. 4, p.711-720, 2007. https://doi.org/10.1590/S0006-87052007000400022

Sabonaro, D. Z. Caracterização da fertilidade do solo, vegetação e interação soloplanta em florestas de restinga do litoral paulista. Rio Claro: Universidade Estadual de São Paulo, 2011.

Santos, D. L.; Sugahara, V. Y.; Takaki, M. Efeitos da luz e da temperatura na germinação de sementes de Tabebuia serratifolia (Vahl) Nich, Tabebuia chrysotricha (Mart. ex DC.) Standl. e Tabebuia roseo-alba (Ridl) Sand - Bignoniaceae. Ciência Florestal, v. 15, no. 1, p. 87-92, 2005. https://doi.org/10.5902/198050981826

Santos, D.; Santos Filho, B.; Torres, S.; Firmino, J.; Smiderle, O. Efeito do substrato e profundidade de semeadura na emergência e desenvolvimento de plântulas de sabiá. Revista Brasileira de Sementes, v. 16, no. 1, p. 50-53, 1994.

São Paulo. Resolução SMA no 11, de 13 de abril de 1992. Estabelece normas para exploração da Caixeta (Tabebuia cassinoides) sob regime de rendimento auto-sustentado no Estado de São Paulo. Available from: <https://www.cetesb.sp.gov.br/licenciamento/ documentos/1992_Res_SMA_11.pdf >. Accessed on: Feb. 23, 2020.

Scarano, F. Structure, function and floristic relationships of plant communities in stressful habitats marginal to the Brazilian Atlantic Rainforest. Annals of Botany, v. 90, no. 4, p. 517-524, 2002 https://doi.org/10.1093/aob/mcf189

Stockman, A. L.; Brancalion, P. H. S.; Novembre, A.; Chamma, H. Sementes de ipê-branco (Tabebuia roseo-alba (Ridl.) Sand.-Bignoniaceae): temperatura e substrato para o teste de germinação. Revista Brasileira de Sementes, v. 29, no. 3, p. 139-143, 2007. https://doi.org/10.1590/S0101-31222007000300016

Tabarelli, M.; Pinto, L. P.; Bedê, L.; Hirota, M.; Silva, J. M. C. Challenges and opportunities for biodiversity conservation in Brazilian Atlantic Forest. Conservation Biology, v. 19, no. 3, p. 695-700, 2005. https://doi.org/10.1111/j.1523-1739.2005.00694.x

Waldhoff, P.; Viana, V. M.; Lima, W. P. Impactos da colheita de madeira de caixeta (Tabebuia cassinoides) na qualidade da água. Scientia Forestalis, n. 59, p. 41-49, 2001.

License information: This is an open-access article distributed under the terms of the Creative Commons Attribution License, which permits unrestricted use, distribution, and reproduction in any medium, provided the original work is properly cited. 